\title{
Effects of Charcoal Production on Soil Physicochemical Properties in Moro Local Government Area of Kwara State, Nigeria
}

\author{
Abdulrasheed Abidemi Adio* ${ }^{\circledR}$, Abiola Omolewa Saliu $\oplus^{\circledR}$, Mariam Abiola Akanbi-Gada $₫$, \\ Bolaji Abiodun Najeemdeen
}

Department of Plant and Environmental Biology, Kwara State University, Malete, Nigeria

Email: *abdulrasheed.adio@kwasu.edu.ng, abiola.ilesanmi@kwasu.edu.ng, mariam.gada@kwasu.edu.ng,

bolaji.najeemdeen13@kwasu.edu.ng

How to cite this paper: Adio, A.A., Saliu, A.O., Akanbi-Gada, M.A. and Najeemdeen, B.A. (2022) Effects of Charcoal Production on Soil Physicochemical Properties in Moro Local Government Area of Kwara State, Nigeria. Journal of Environmental Protection, 13, 220-232.

https://doi.org/10.4236/jep.2022.132014

Received: November 15, 2021

Accepted: February 15, 2022

Published: February 18, 2022

Copyright $\odot 2022$ by author(s) and Scientific Research Publishing Inc. This work is licensed under the Creative Commons Attribution International License (CC BY 4.0).

http://creativecommons.org/licenses/by/4.0/ (c) (i) Open Access

\begin{abstract}
Charcoal production is a major economic activity in rural Kwara State, North-Central Nigeria. Given that it generally involves the use of traditional earth kilns, this study was designed to investigate the effects of charcoal production on the physical and chemical properties of soil. Replicate soil core samples were collected within a depth of $0-20 \mathrm{~cm}$ from 19 charcoal kiln sites (CKS) and 19 adjacent control sites (ACS) across five administrative districts in the study area. These samples were subjected to laboratory analysis to determine their physical and chemical qualities and then $\mathrm{t}$-test was used to statistically compare the CKS and ACS soils. There was no significant difference in soil texture between both sites. However, CKS soil pH and electrical conductivity significantly increased $(\mathrm{p}<0.01)$ by $9.12 \%$ and $17.80 \%$, respectively. Conversely, charcoal production led to a significant decrease $(\mathrm{p}<0.001)$ of extractable acidity at a rate of $24.05 \%$. Total organic carbon, organic matter, total nitrogen, carbon to nitrogen ratio, and available phosphorus increased slightly $(\mathrm{p}>0.05)$ due to charred biomass introduced to soils by the process of charcoal production. The CKS cation exchange capacity, Ca and Mg increased significantly $(\mathrm{p}<0.0001)$ by $40.11 \%, 57.15 \%$ and $89.16 \%$, respectively. Charcoal production significantly reduced Fe by $28.54 \%$, while the concentration of other heavy metals remained similar between both sites. The findings showed that charcoal production using traditional earth kilns improves soil physical and chemical properties for agriculture purposes. However, further studies are suggested to understand its effects on vegetation cover and soil biota.
\end{abstract}

\section{Keywords}

Charcoal Production, Earth Kiln, Soil Properties, Guinea Savanna, Soil 
Properties

\section{Introduction}

Woodfuel production is an essential ecological service provided by dry forests and woodlands. Increased population and continuous outrageous increases in the pricing of alternative energy sources, particularly kerosene, have given significance to the charcoal business, which is currently spreading rapidly across $\mathrm{Ni}$ geria [1].

As a result of the country's significant poverty rate, more than $60 \%$ of the $\mathrm{Ni}$ gerian people relied on fuelwood and charcoal as their primary energy sources for cooking [2]. Charcoal production through selective logging of favoured hardwood species, has the potential to change the physiognomic composition of residual or re-growth woods, resulting in their deterioration and degradation [3]. Annual deforestation is expected to be around 400,000 hectares, compared to 1.043 hectares of replanting and report has it that the annual rate of deforestation increased from 0.7 percent in 1980-1990 to 0.9 percent in 1990/1995 and 2.6 percent in 1990/2000 [4]. Forest resource loss can result in decreased income and food-generating capability for forest-dependent people, increased soil and canal siltation, loss of species and genetic diversity, and increased carbon emissions, all of which contribute to global warming [5] [6]. Fish smoking, garri frying, maize/plantain roasting, blacksmithing, and other small-scale processing operations employ charcoal. Despite efforts to deter its end use, nearly $80 \%$ percent of the African population use charcoal as the main source of energy for cooking [7]. Due to its cultural preference [8], this fuel will continue to be a part of the fuel ladder for many countries. According to Food and Agriculture Organization [9], the charcoal production in Africa grew by $12.6 \%$ between 2010 and 2016 and in West Africa by $14.3 \%$.

However, if rainfall occurs after the harvest of charcoal, the biomass materials will be converted to biochar for soil amendment, resulting in a large increase in microbial efficiency (measured in units of $\mathrm{CO}_{2}$ emitted per microbial biomass carbon in the soil) and basal respiration [10]. As reported by previous researchers, increased soil nutrients and organic matter are the resultant effects of charcoal production [11] [12]. Oguntunde et al. reported significant increase in soil $\mathrm{pH}$, base saturation, electrical conductivity, exchangeable $\mathrm{Ca}, \mathrm{Mg}, \mathrm{K}, \mathrm{Na}$ and available $\mathrm{P}$ in the soil at kiln sites as compared to the adjacent soils, an implication of its value not only as a soil conditioner but also a fertilizer [13] [14]. Positive effects on soil properties, soil fertility and productivity have also been reported [15].

The goal of this study was to determine the influence of charcoal production on the physical and chemical properties of soil in Moro Local Government Area of Kwara State, Nigeria. 


\section{Materials and Methods}

\subsection{Study Area}

The study was conducted in Moro Local Government Area of Kwara State in North-Central Nigeria in Figure 1. It is situated around latitude N8.94225 $5^{\circ}$, longitude $\mathrm{E} 4.77804^{\circ}$, and an altitude of about $300 \mathrm{~m}$ above sea level. The area lies within the guinea savanna ecoregion with marked seasonality. It is characterized by a mean annual rainfall of $1200 \mathrm{~mm}$ with a wet season that spans April to October and a dry season from November to March. It has a warm average annual temperature of $26.2^{\circ} \mathrm{C}$ rising to a peak of $30^{\circ} \mathrm{C}$ in March [16] [17] [18]. A reconnaissance conducted in August 2019 as part of this study revealed evidence of various activities in the charcoal value-chain across the study area including kilns, charcoal storage depots, retail points, and haulage. Hence, charcoal business is an important economic activity in the study area.

\subsection{Sampling Strategy}

A total of 19 kilns were purposefully selected from five administrative districts within the study area (Table 1) between July and September 2020. The inclusion criteria include kilns not older two months [11] as well as security accessibility to a sampling point due to the recent ban on charcoal production and activities of the task force set up by the State Government [19] [20]. Locals involved in charcoal production activities were recruited in this regard. Soil core samples were collected using a soil auger from a depth of $0-20 \mathrm{~cm}$ at each sampling point. The soil cores were taken in duplicates from each kiln (coded CKS for charcoal kiln soil) and from an adjacent control site (coded ACS for adjacent

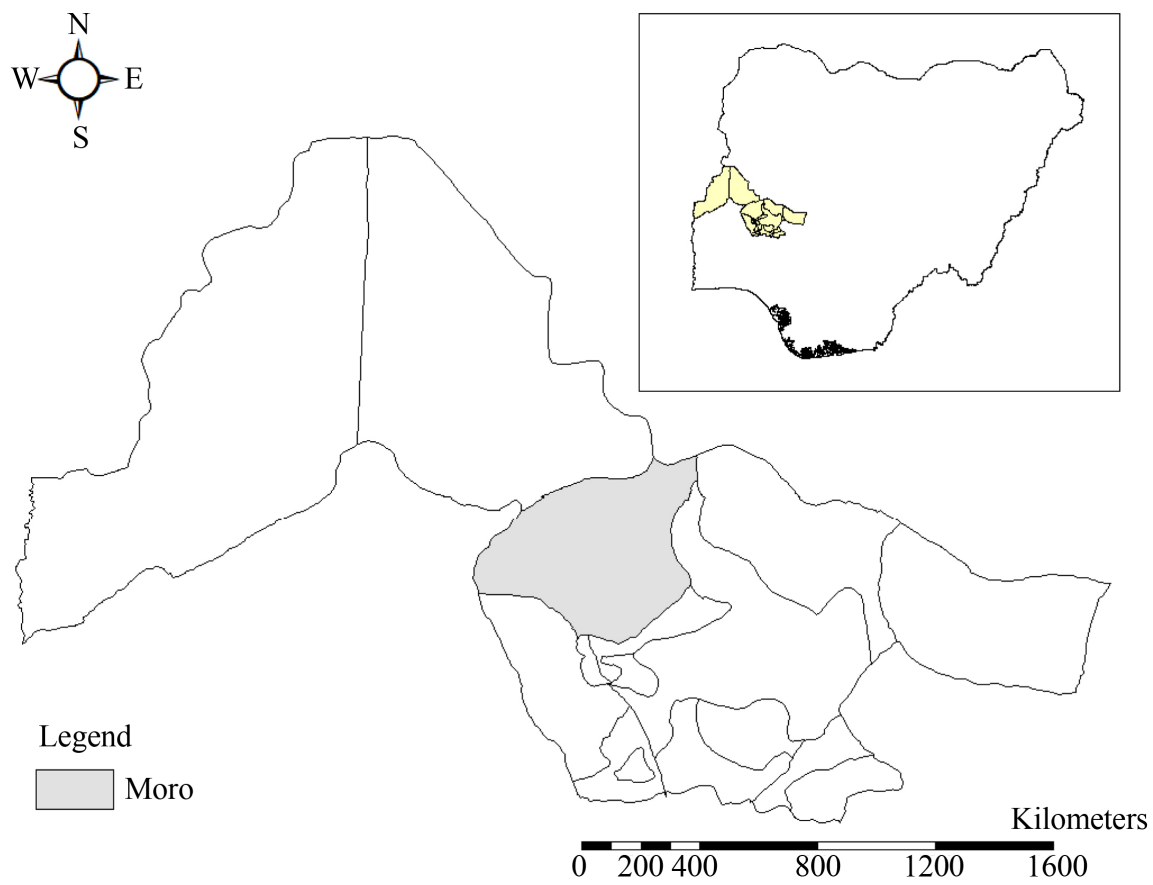

Figure 1. Map of Kwara State showing the study area (Inset: Nigeria). 
Table 1. Geospatial attributes of sampling points.

\begin{tabular}{|c|c|c|c|c|c|c|}
\hline $\mathrm{S} / \mathrm{N}$ & District & $\begin{array}{c}\text { Northing } \\
\left({ }^{\circ}\right)\end{array}$ & $\begin{array}{c}\text { Easting } \\
\left({ }^{\circ}\right)\end{array}$ & $\begin{array}{c}\text { Elevation } \\
(\mathrm{m})\end{array}$ & $\begin{array}{l}\text { Kiln age } \\
\text { (month) }\end{array}$ & $\begin{array}{l}\text { Surrounding } \\
\text { activity }\end{array}$ \\
\hline 1. & Malete & 8.73989 & 4.48416 & 345 & $<2$ & Bush \\
\hline 2. & Malete & 8.72132 & 4.40890 & 350 & $<1$ & Bush \\
\hline 3. & Malete & 8.68605 & 4.44361 & 360 & $<1$ & Bush \\
\hline 4. & Malete & 8.71582 & 4.46188 & 337 & $<1$ & Residential \\
\hline 5. & Bode Saadu & 8.86875 & 4.72266 & 283 & $<2$ & $\begin{array}{c}\text { Beside national } \\
\text { highway } \\
\text { (Ilorin-Jebba) }\end{array}$ \\
\hline 6. & Bode Saadu & 8.86140 & 4.73695 & 239 & $<2$ & Farmland \\
\hline 7. & Shao & 8.63240 & 4.53079 & 313 & $<1$ & $\begin{array}{c}\text { Military } \\
\text { shooting range }\end{array}$ \\
\hline 8. & Shao & 8.62874 & 4.52861 & 311 & $<1$ & Farmland \\
\hline 9. & Shao & 8.62375 & 4.53147 & 327 & $<1$ & Bush \\
\hline 10. & Shao & 8.61744 & 4.54881 & 270 & $<1$ & Bush \\
\hline 11. & Shao & 8.61912 & 4.54478 & 283 & $<1$ & Bush \\
\hline 12. & Olooru & 8.64077 & 4.60747 & 296 & $<1$ & Bush \\
\hline 13. & Olooru & 8.63487 & 4.61488 & 276 & $<1$ & Bush \\
\hline 14. & Olooru & 8.65491 & 4.59971 & 300 & $<1$ & Bush \\
\hline 15. & Olooru & 8.65433 & 4.60109 & 301 & $<1$ & Bush \\
\hline 16. & Olooru & 8.65743 & 4.59025 & 298 & $<1$ & Residential \\
\hline 17. & Lanwa & 8.76171 & 4.74598 & 277 & $<1$ & Bush \\
\hline 18. & Lanwa & 8.76514 & 4.74586 & 280 & $<1$ & Farmland \\
\hline 19. & Lanwa & 8.77400 & 4.74685 & 278 & $<1$ & Bush \\
\hline
\end{tabular}

control soil) about $5-15 \mathrm{~cm}$ from the edge of the reference kiln. Therefore, 38 CKS along with complimentary 38 ACS were collected in polythene bags and transported to the laboratory.

\subsection{Laboratory Analysis}

The soil samples were air-dried at the laboratory and sieved through a $2 \mathrm{~mm}$ mesh before analysis to determine the physicochemical properties of the soil samples including soil particle size, bulk density, $\mathrm{pH}$, electrical conductivity, extractable acidity, total nitrogen, available phosphorus, total organic carbon, organic matter, calcium ion, magnesium ion, sodium ion, potassium ion, cation exchange capacity, and heavy metals (copper, manganese, iron, lead, chromium, cadmium).

An improved hydrometer method was used to determine the percent distribution of sand, silt, and clay particles in the soil samples [21] [22]. Soil pH was determined by an electrometric method using a 1:2.5 soil to water ratio, wherein 20 
$\mathrm{g}$ of soil was added to $50 \mathrm{ml}$ of distilled water and the value measured with the electrode of a pH meter [22] [23]. Electrical conductivity was determined by adding $100 \mathrm{ml}$ distilled water to $20 \mathrm{~g}$ of the soil samples and measured using a conductivity meter [24]. Extractable acidity was determined by centrifuging a mixture of the soil sample with $\mathrm{BaCl}_{2}$-TEA buffer solution then an aliquot of the supernatant solution was titrated with acid [25]. Total nitrogen was determined using the micro-Kjeldahl procedure. Available phosphorous was determined using the Olsen method. Total organic carbon was determined with the Walkey-Black wet oxidation method [25].

To determine exchangeable $\mathrm{Ca}^{2+}, \mathrm{Mg}^{2+}, \mathrm{K}^{+}, \mathrm{Na}^{+}$and effective cation exchange capacity (CEC) in soil, $30 \mathrm{ml}$ of $1 \mathrm{~N} \mathrm{NH}_{3} \mathrm{OAC}$ was added to $5 \mathrm{~g}$ of the soil sample and was shaken using a mechanical shaker for $2 \mathrm{hrs}$. The solution was then centrifuged carefully at $2.00 \mathrm{rpm}$ for $5-10$ mins and the supernatant was carefully decanted into a $100 \mathrm{~mL}$ volumetric flask. Another $30 \mathrm{~mL}$ of $\mathrm{NH}_{4} \mathrm{OAC}$ solution was added and the flask was shaken for 30 minutes. It was then centrifuged, and the supernatant was transferred into the same volumetric flask. The step was repeated thrice, and the supernatants were transferred into the same volumetric flask which was used to mark up with the $\mathrm{NH}_{4} \mathrm{OAC}$ solution. The concentrations of these cations were determined using flame photometer and atomic absorption spectrophotometer [25] [26] [27].

A wet digestion method was used to prepare soil samples for determining the concentration of heavy metals $(\mathrm{Cu}, \mathrm{Mn}, \mathrm{Pb}, \mathrm{Fe}, \mathrm{Cr}$, and $\mathrm{Cd})$ using atomic absorption spectrophotometry. A mixture of $1 \mathrm{~g}$ soil sample, $5 \mathrm{ml}$ concentrated $\mathrm{HCl}$ and $15 \mathrm{ml} \mathrm{HNO}_{3}$ was heated on a hot plate in a fume-hood at a temperature between $50^{\circ} \mathrm{C}-60^{\circ} \mathrm{C}$ until the brownish fume color was expelled. The mixture was allowed to cool at room temperature then $5 \mathrm{ml}$ of distilled water added. The resulting mixture was filtered into a clean plastic container using Whatman filter paper and made up to $50 \mathrm{ml}$ in a standard flask with distilled water. Each digested sample was transferred into plastic containers for heavy metal analysis using a BUCK Scientific ACCUSYS 211 Atomic Absorption Spectrophotometer.

\subsection{Data Analysis}

The difference in the soil parameters between CKS and ACS was assessed using the Student's $t$ test with the critical significance level $(\alpha)$ set at 0.05 . The relative change in each soil parameter between both site categories was determined using the formula below.

$$
\text { Relative Change }(\%)=\frac{P_{c}-P_{a}}{P_{a}} \times 100 \%
$$

where $P_{c}$ and $P_{a}$ are the CKS and ACS soil parameter, respectively.

\section{Results and Discussion}

\subsection{Effect of Charcoal Production on Soil Physical Properties}

The variation of the physical properties of the soil at ACS and CKS are presented 
in Figure 2, while Table 2 outlines the mean \pm standard error of the mean, relative change, and statistical difference of these properties. Although the silt and clay fractions of the soil were not significantly different between both sites, they exhibited slight decrease of $3.25 \%$ and $1.03 \%$ at the charcoal kiln sites, respectively. However, the sand fraction increased by $1.59 \%$ at the charcoal sites. These findings are consistent with those of previous researchers [11] [28]. The marked increased in soil temperatures due to charcoal production might have led to the fusion of silt and clay particles into sand-sized ones [29] [30]. This coarsening process may adversely affect the water holding capacity of the severely heated soil surface [31].

There was also no significant difference in the soil bulk density, however, it slightly reduced by $0.68 \%$ at the charcoal kiln sites. Nigussie and Kissi suggest that this could be due to the complex pore structure of charcoal residues left on the kiln site as well as the increased sand fraction at these sites as discussed above [28].

\subsection{Effect of Charcoal Production on Soil pH, Electrical Conductivity, and Extractable Acidity}

Soil $\mathrm{pH}$ exhibited a very high significant difference $(\mathrm{p}<0.001)$ between the charcoal kiln sites and adjoining control sites (Table 3). The soil in the study area

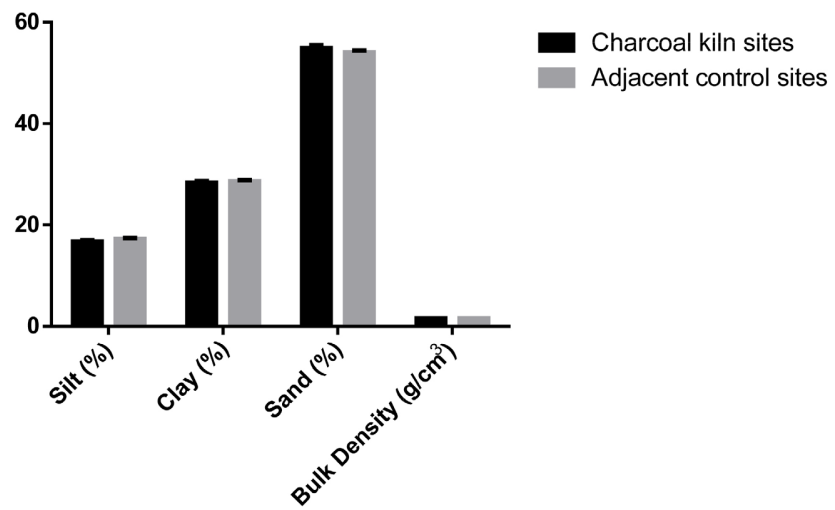

Figure 2. Mean \pm SE of physical properties of soil at charcoal kiln sites and adjacent control sites.

Table 2. Selected summary statistics, relative change, and statistical significance of physical properties of soil at charcoal kiln sites and adjacent control sites.

\begin{tabular}{ccccc}
\hline & $\begin{array}{c}\text { Silt } \\
(\%)\end{array}$ & $\begin{array}{c}\text { Clay } \\
(\%)\end{array}$ & $\begin{array}{c}\text { Sand } \\
(\%)\end{array}$ & $\begin{array}{c}\text { Bulk density } \\
\left(\mathbf{g} / \mathrm{cm}^{3}\right)\end{array}$ \\
\hline Adjacent control sites (ACS) & $17.30 \pm 0.13$ & $28.63 \pm 0.25$ & $54.07 \pm 0.36$ & $1.58 \pm 0.01$ \\
Charcoal kiln sites (CKS) & $16.74 \pm 0.29$ & $28.34 \pm 0.33$ & $54.93 \pm 0.56$ & $1.57 \pm 0.01$ \\
Relative change (\%) & -3.25 & -1.03 & 1.59 & -0.68 \\
p-value & $\mathrm{ns}$ & $\mathrm{ns}$ & $\mathrm{ns}$ & $\mathrm{ns}$ \\
\hline
\end{tabular}

ns = not significant. 
Table 3. Selected summary statistics, relative change, and statistical significance of soil $\mathrm{pH}$, electrical conductivity, and extractable acidity at charcoal kiln sites and adjacent control sites.

\begin{tabular}{cccc}
\hline & $\mathrm{pH}$ & $\begin{array}{c}\text { Electrical conductivity } \\
\left(\mathrm{mmhos} / \mathrm{cm}^{3}\right)\end{array}$ & $\begin{array}{c}\text { Extractable acidity } \\
(\mathrm{meq} / \mathbf{1 0 0})\end{array}$ \\
\hline Adjacent control sites (ACS) & $7.81 \pm 0.06$ & $21.41 \pm 1.10$ & $0.88 \pm 0.02$ \\
Charcoal kiln sites (CKS) & $8.52 \pm 0.05$ & $25.22 \pm 0.88$ & $0.67 \pm 0.02$ \\
Relative change (\%) & 9.12 & 17.80 & -24.05 \\
p-value & $<0.001$ & $<0.01$ & $<0.001$ \\
\hline
\end{tabular}

is typically neutral, however, charcoal production appears to have increased the $\mathrm{pH}$ by $9.12 \%$ in agreement with the findings of Nigussie and Kissi, and Chima et al. [32] [33]. The ash residue at the charcoal kilns has been suggested to be responsible for this increase in $\mathrm{pH}$. Furthermore, the porous nature of charcoal increases exchange of bases (cation exchange capacity) of soils. Thereby improving the possibility of $\mathrm{Al}$ and $\mathrm{Fe}$ to bind with the exchange site [34] [35].

The electrical conductivity of the soil exhibited a high significant difference ( $\mathrm{p}$ $<0.01$ ), increasing by about $17.8 \%$ at the charcoal kiln sites relative to the adjacent control sites. This is also indicative of the presence of ash, which is known to have abundance of exchangeable cations. Similar patterns of difference in soil electrical conductivity have been reported by previous researchers [11] [32].

Figure 3, extractable acidity showed a very high significant difference $(\mathrm{p}<$ 0.001 ) between the charcoal kiln sites and the adjacent control sites. In variance to $\mathrm{pH}$ and electrical conductivity, the extractable acidity of the soil reduced by about $24 \%$ at the charcoal kiln sites. Nigusiie and Kissi [32] reported a significant negative correlation between extractable acidity and $\mathrm{pH} /$ electrical conductivity.

\subsection{Effect of Charcoal Production on Organic Carbon, Organic Matter, Total Nitrogen, and Available Phosphorus}

Charcoal production did not significantly affect the soil organic carbon, organic matter, total nitrogen, carbon to nitrogen ratio, and available phosphorus relative to the adjacent control sites. Ogundele et al. reported similar findings for organic carbon and nitrogen in a nearby ecosystem [36]. However, in Figure 4, the observed increase in carbon, nitrogen and organic matter in soils directly beneath the kilns may be due to charcoal residue. Similarly, the increase in available phosphorus by $19.9 \%$ in the charcoal kiln soil may be due to wood ash that is characterized by high phosphorus content [28] (Table 4).

\subsection{Effect of Charcoal Production on Cation Exchange Capacity and Exchangeable Bases}

Charcoal production significantly affected the cation exchange capacity ( $\mathrm{p}<$ 0.001 ), increasing its value by $40.11 \%$ relative to the adjacent control sites. This 


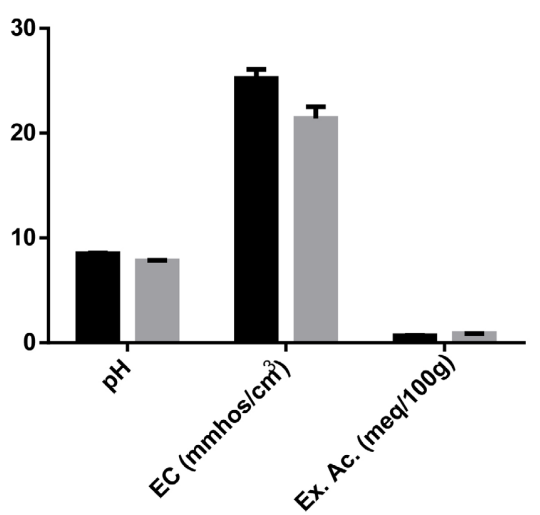

Figure 3. Mean \pm SE of soil $\mathrm{pH}$, electrical conductivity, and extractable acidity at charcoal kiln sites and adjacent control sites.

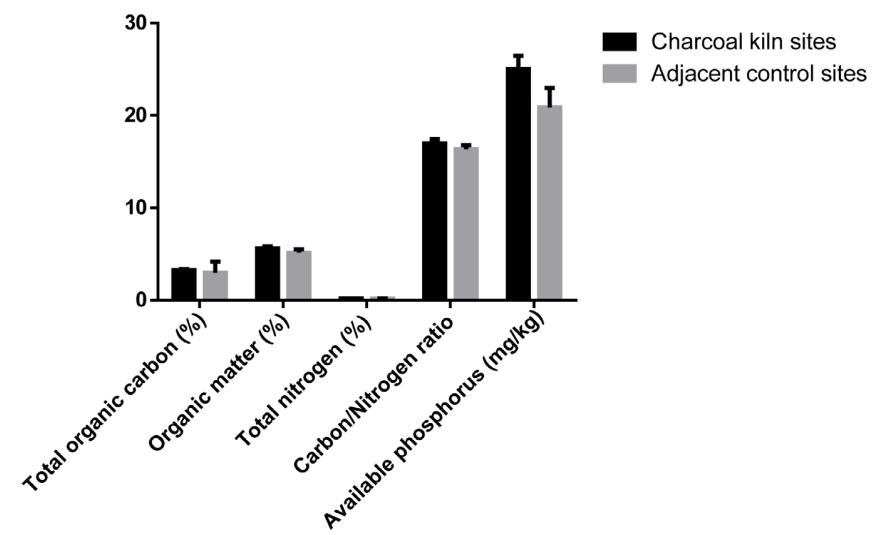

Figure 4. Mean \pm SE of soil organic carbon, organic matter, total nitrogen and available phosphorus at charcoal kiln sites and adjacent control sites.

Table 4. Selected summary statistics, relative change, and statistical significance of organic carbon, organic matter, total nitrogen and available phosphorus of soil at charcoal kiln sites and adjacent control sites.

\begin{tabular}{cccccc}
\hline & $\begin{array}{c}\text { TOC } \\
(\%)\end{array}$ & $\begin{array}{c}\text { OM } \\
(\%)\end{array}$ & $\begin{array}{c}\text { TN } \\
(\%)\end{array}$ & C/N & $\begin{array}{c}\text { AvP } \\
(\mathrm{mg} / \mathrm{kg})\end{array}$ \\
\hline $\begin{array}{c}\text { Adjacent control } \\
\text { sites (ACS) }\end{array}$ & $2.98 \pm 0.22$ & $5.14 \pm 0.38$ & $0.19 \pm 0.02$ & $16.37 \pm 0.42$ & $20.88 \pm 2.11$ \\
$\begin{array}{c}\text { Charcoal kiln } \\
\text { sites (CKS) }\end{array}$ & $3.26 \pm 0.12$ & $5.62 \pm 0.21$ & $0.20 \pm 0.01$ & $16.98 \pm 0.45$ & $25.04 \pm 1.39$ \\
$\begin{array}{c}\text { Relative change (\%) } \\
\text { p-value }\end{array}$ & 9.11 & 9.33 & 6.19 & 3.70 & 19.90 \\
\hline
\end{tabular}

TOC $=$ Total Organic Carbon, $\mathrm{OM}=$ Organic Matter, $\mathrm{TN}=$ Total Nitrogen, AvP = Available Phosphorus, $\mathrm{C} / \mathrm{N}=$ Carbon to Nitrogen ratio, $\mathrm{ns}=$ not significant.

conforms with the findings and suggestion of Nigussie and Kissi that this increase could be due to charcoal residue and other charred matter at the kiln sites [32]. Addition of biochar to soil has also been shown to increase cation exchange capacity [37]. 
In Figure 5, two of the exchangeable bases ( $\mathrm{Ca}$ and $\mathrm{Mg}$ ) significantly increased $(\mathrm{p}<0.001)$ at the charcoal kiln sites by $57.15 \%$ and $89.16 \%$, respectively. However, Na slightly increased by $3.30 \%$ while K reduced by $0.29 \%$. The release of minerals has been correlated with the deposition of ash due to its richness in basic cations [38]. Awodun et al., Kishor et al., and Nigussie and Kissi all reported a significant increase in exchangeable bases at their respective burn sites [32] [39] [40]. Furthermore, our non-significant findings on exchangeable $\mathrm{Na}$ and $\mathrm{K}$ are similar to those of Ogundele et al. [36]. This could be due to the proximity of our study locations (Table 5).

\subsection{Effect of Charcoal Production on Heavy Metals}

Most of the heavy metals investigated did not significantly change between both sites. Only $\mathrm{Fe}$ exhibited a significant $(\mathrm{p}<0.001$ ) reduction of $28.54 \%$ at the charcoal kiln sites. Mn and Cr also slightly reduced by $16.28 \%$ and $6.35 \%$, respectively. Lehmann [41] explained that the bioavailability of heavy metals is reduced when $\mathrm{COO}, \mathrm{OH}$ and other functional groups on the surface of biochar form complexes with heavy metals in Figure 6. $\mathrm{Pb}$ and $\mathrm{Cd}$ were largely below the detection limits of the methods used in this study. This could be because the study areas are rural with minimal industrial activities (Table 6).

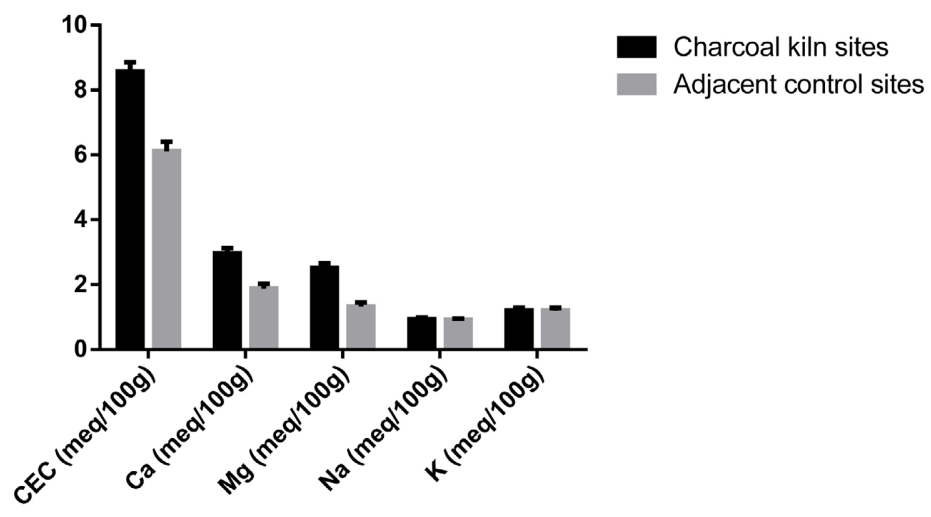

Figure 5. Mean \pm SE of cation exchange capacity and exchangeable bases at charcoal kiln sites and adjacent control sites.

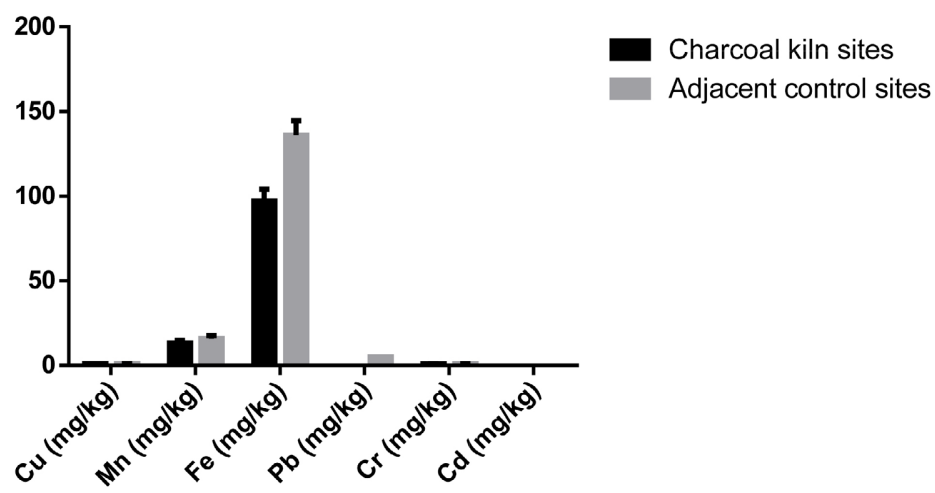

Figure 6. Mean \pm SE of heavy metals at charcoal kiln sites and adjacent control sites. 
Table 5. Selected summary statistics, relative change, and statistical significance of cation exchange capacity and exchangeable bases of soil at charcoal kiln sites and adjacent control sites.

\begin{tabular}{cccccc}
\hline & $\begin{array}{c}\mathrm{CEC} \\
(\mathrm{meq} / 100 \mathrm{~g})\end{array}$ & $\begin{array}{c}\mathrm{Ca} \\
(\mathrm{meq} / 100 \mathrm{~g})\end{array}$ & $\begin{array}{c}\mathrm{Mg} \\
(\mathrm{meq} / 100 \mathrm{~g})\end{array}$ & $\begin{array}{c}\mathrm{Na} \\
(\mathrm{meq} / 100 \mathrm{~g})\end{array}$ & $\begin{array}{c}\mathrm{K} \\
(\mathrm{meq} / 100 \mathrm{~g})\end{array}$ \\
\hline $\begin{array}{c}\text { Adjacent control } \\
\text { sites (ACS) }\end{array}$ & $6.11 \pm 0.29$ & $1.88 \pm 0.15$ & $1.33 \pm 0.12$ & $0.91 \pm 0.04$ & $1.20 \pm 0.09$ \\
$\begin{array}{c}\text { Charcoal kiln sites } \\
\text { (CKS) }\end{array}$ & $8.56 \pm 0.29$ & $2.96 \pm 0.17$ & $2.51 \pm 0.14$ & $0.94 \pm 0.04$ & $1.20 \pm 0.09$ \\
$\begin{array}{c}\text { Relative change } \\
(\%)\end{array}$ & 40.11 & 57.15 & 89.16 & 3.30 & -0.29 \\
\begin{tabular}{c} 
p-value \\
\hline
\end{tabular} & $<0.0001$ & $<0.0001$ & $<0.0001$ & $\mathrm{~ns}$ & $\mathrm{~ns}$ \\
\hline
\end{tabular}

$\mathrm{CEC}=$ Cation Exchange Capacity, $\mathrm{ns}=$ not significant.

Table 6. Selected summary statistics, relative change, and statistical significance of heavy metals at charcoal kiln sites and adjacent control sites.

\begin{tabular}{ccccccc}
\hline & $\begin{array}{c}\mathrm{Cu} \\
(\mathrm{mg} / \mathrm{kg})\end{array}$ & $\begin{array}{c}\mathrm{Mn} \\
(\mathrm{mg} / \mathrm{kg})\end{array}$ & $\begin{array}{c}\mathrm{Fe} \\
(\mathrm{mg} / \mathrm{kg})\end{array}$ & $\begin{array}{c}\mathrm{Pb} \\
(\mathrm{mg} / \mathrm{kg})\end{array}$ & $\begin{array}{c}\mathrm{Cr} \\
(\mathrm{mg} / \mathrm{kg})\end{array}$ & $\begin{array}{c}\mathrm{Cd} \\
(\mathrm{mg} / \mathrm{kg})\end{array}$ \\
\hline Adjacent & 1.17 & 15.92 & 136.03 & 5.00 & 1.06 & \\
control sites & \pm & \pm & \pm & \pm & \pm & $\mathrm{ND}$ \\
(ACS) & 0.11 & 1.73 & 8.63 & 0.00 & 0.08 & \\
Charcoal & 1.23 & 13.33 & 97.20 & & 0.99 & \\
kiln sites & \pm & \pm & \pm & $\mathrm{ND}$ & \pm & $\mathrm{ND}$ \\
(CKS) & 0.09 & 1.39 & 6.88 & & 0.09 & \\
Relative change (\%) & 4.70 & -16.28 & -28.54 & $\mathrm{NA}$ & -6.35 & $\mathrm{NA}$ \\
p-value & $\mathrm{ns}$ & $\mathrm{ns}$ & $<0.001$ & $\mathrm{~ns}$ & $\mathrm{~ns}$ & $\mathrm{~ns}$ \\
\hline
\end{tabular}

$\mathrm{ND}=$ Not Detected, $\mathrm{NA}=$ Not Applicable, $\mathrm{ns}=$ not significant.

\section{Conclusion}

Charcoal production did not significantly affect soil physical properties, although a slight increase in sand percentage was observed at kiln sites while silt, clay and bulk density reduced to a small degree in relation to the adjacent control sites. Soil $\mathrm{pH}$ and electrical conductivity significantly increased at the kiln sites. However, total extractable acidity reduced significantly due to its negative correlation with $\mathrm{pH}$ and electrical conductivity. Total organic carbon, organic matter, total nitrogen, carbon to nitrogen ratio, and available phosphorus increased slightly due to charred biomass introduced to soils by the process of charcoal production. The increased quantity of ash at the kiln sites led to a significant increase in the cation exchange capacity and most of the exchangeable bases in the affected soils. Charcoal production also reduced the bioavailability of heavy metals. Conclusively, charcoal production does not appear to cause irreversible adverse effects on soil physical and chemical properties. However, further studies will be useful in understanding the effects of charcoal production 
on vegetation cover and soil biota.

\section{Acknowledgements}

This study was conducted under the Institutional Based Research (IBR) of Kwara State University, funded by the Tertiary Education Trust Fund (TETFund), Nigeria.

\section{Conflicts of Interest}

The authors declare no conflicts of interest regarding the publication of this paper.

\section{References}

[1] Chima, U.D. (2006) Nigeria: The Devastating Flames of Abacha Coal-Pots and the People's Forests. World Rainforest Movement. https://wrm.org.uy/articles-from-the-wrm-bulletin/section1/nigeria-the-devastating -flames-of-abacha-coal-pots-and-the-peoples-forests/

[2] Akinbami, J.-F.K., Salami, A.T. and Siyanbola, W.O. (2003) An Integrated Strategy for Sustainable Forest-Energy-Environment Interactions in Nigeria. Journal of Environmental Management, 69, 115-128. https://doi.org/10.1016/S0301-4797(03)00083-5

[3] Ndegwa, G.M., Nehren, U., Grüninger, F., Iiyama, M. and Anhuf, D. (2016) Charcoal Production through Selective Logging Leads to Degradation of Dry Woodlands: A Case Study from Mutomo District, Kenya. Journal of Arid Land, 8, 618-631. https://doi.org/10.1007/s40333-016-0124-6

[4] Ibrahim, D.C. (2005) The Role of Afforestation in Preserving the Environment of Bauchi State in Nigeria. International Journal of Environmental Issues, 3, 156-161.

[5] Amede, T., Belachew, T. and Geta, E. (2001) Reversing the Degradation of Arable Land in the Ethiopian Highlands. Managing Africa's Soils No. 23, Areka Research Centre, Areka, 29 p.

[6] Tchobsala, Dieudonne, R., Adamou, I. and Marie, M. (2016) Impact of Wood Cutting and Bush Fire on the Dynamic of Regeneration in the Guinea Savanna of Adamawa Region. International Journal of Current Research in Biosciences and Plant Biology, 3, 114-131. https://doi.org/10.20546/ijcrbp.2016.309.015

[7] Zulu, L.C. and Richardson, R.B. (2013) Charcoal, Livelihoods, and Poverty Reduction: Evidence from Sub-Saharan Africa. Energy for Sustainable Development, 17, 127-137. https://doi.org/10.1016/j.esd.2012.07.007

[8] Akpalu, W., Dasmani, I. and Aglobitse, P.B. (2011) Demand for Cooking Fuels in a Developing Country: To What Extent Do Taste and Preferences Matter? Energy Policy, 39, 6525-6531. https://doi.org/10.1016/j.enpol.2011.07.054

[9] Food and Agriculture Organization Corporate Statistical Database (2021) Forestry Production and Trade. Food and Agricultural Organization, Rome. https://www.fao.org/faostat/en/\#data/FO

[10] Steiner, C., Glaser, B., Geraldes Teixeira, W., Lehmann, J., Blum, W.E.H. and Zech, W. (2008) Nitrogen Retention and Plant Uptake on a Highly Weathered Central Amazonian Ferralsol Amended with Compost and Charcoal. Journal of Plant Nutrition and Soil Science, 171, 893-899. https://doi.org/10.1002/jpln.200625199

[11] Oguntunde, P.G., Abiodun, B.J., Ajayi, A.E. and van de Giesen, N. (2008) Effects of 
Charcoal Production on Soil Physical Properties in Ghana. Journal of Plant Nutrition and Soil Science, 171, 591-596. https://doi.org/10.1002/jpln.200625185

[12] Fontodji, J., Mawussi, G., Nuto, Y. and Kokou, K. (2010) Effects of charcoal production on Soil Biodiversity and Soil Physical and Chemical Properties in Togo, West Africa. International Journal of Biological and Chemical Sciences, 3, 870-879. https://doi.org/10.4314/ijbcs.v3i5.51051

[13] Glaser B., Lehmann, J. and Zech, W. (2002) Ameliorating Physical and Chemical Properties of Highly Weathered Soils in the Tropics with Charcoal-A Review. Biology and Fertility of Soils, 35, 219-230. https://doi.org/10.1007/s00374-002-0466-4

[14] Oguntunde, P.G., Fosu, M., Ajayi, A.E. and van de Giesen, N. (2004) Effects of Charcoal Production on Maize Yield, Chemical Properties and Texture of Soil. Biology and Fertility of Soils, 39, 295-299. https://doi.org/10.1007/s00374-003-0707-1

[15] Ketterings, Q.M. and Bigham, J.M. (2000) Soil Color as an Indicator of Slash-and-Burn Fire Severity and Soil Fertility in Sumatra, Indonesia. Soil Science Society of America Journal, 64, 1826-1833. https://doi.org/10.2136/sssaj2000.6451826x

[16] Aweto, A.O. and Adejumobi, D.O. (1991) Impact of Grazing on Soil in the Southern Guinea Savanna Zone of Nigeria. Environmentalist, 11, 27-32.

https://doi.org/10.1007/BF01263195

[17] Federal Department of Forestry (2019) National Forest Reference Emission Level (FREL) for the Federal Republic of Nigeria. Federal Department of Forestry. https://redd.unfccc.int/files/2019_submission_frel_nigeria.pdf

[18] Orosun, M.M., Oniku, S.A., Peter, A., Orosun, R.O., Salawu, N.B. and Hitler, L. (2020) Magnetic Susceptibility Measurement and Heavy Metal Pollution at an Automobile Station in Ilorin, North-Central Nigeria. Environmental Research Communications, 2, Article ID: 015001. https://doi.org/10.1088/2515-7620/ab636a

[19] Akinyemi, D. (2018, July 3) Kwara Gov Bans Charcoal Production, Trade. Vanguard News.

https://www.vanguardngr.com/2018/07/kwara-gov-bans-charcoal-production-trade/

[20] Olanrewaju, L. (2018, July 12) Kwara Gov. Sets up Task Force on Tree Felling, Charcoal Production. The Sun Nigeria.

https://www.sunnewsonline.com/kwara-gov-sets-up-task-force-on-tree-felling-char coal-production/

[21] Bouyoucos, G.J. (1962) Hydrometer Method Improved for Making Particle Size Analyses of Soils1. Agronomy Journal, 54, 464-465. https://doi.org/10.2134/agronj1962.00021962005400050028x

[22] Margesin, R. and Schinner, F. (2005) Manual for Soil Analysis: Monitoring and Assessing Soil Bioremediation. Vol. 5, Springer, Heidelberg.

https://doi.org/10.1007/3-540-28904-6

[23] Clark, J.S. (1966) The pH Values of Soils Suspended in Dilute Salt Solutions. Soil Science Society of America Journal, 30, 11-14. https://doi.org/10.2136/sssaj1966.03615995003000010011x

[24] Food and Agricultural Organization (2021) Standard Operating Procedure for Soil Electrical Conductivity. Soil/Water, 1:5. Food and Agricultural Organization, Rome. https://horizon.documentation.ird.fr/exl-doc/pleins_textes/divers21-02/010081188. pdf

[25] van Reeuwijk, L.P. (2002) Procedures for Soil Analysis. 6th Edition, International Soil Reference and Information Centre, Wageningen. https://www.isric.org/sites/default/files/ISRIC_TechPap09.pdf

[26] Jackson, M.L. (1964) Soil Chemical Analysis. Prentice Hall Verlag, Hobken. 
[27] Juo, A.S.R., Ayanlaja, S.A. and Ogunwale, J.A. (1976) An Evaluation of Cation Exchange Capacity Measurements for Soils in the Tropics. Communications in Soil Science and Plant Analysis, 7, 751-761. https://doi.org/10.1080/00103627609366684

[28] Nigussie, A. and Kissi, E. (2011) Effect of Charcoal Production on Soil Properties in Southwestern Ethiopia. Middle East Journal of Scientific Research, 9, 807-813.

[29] Sertsu, S.M. and Sánchez, P.A. (1978) Effects of Heating on Some Changes in Soil Properties in Relation to an Ethiopian Land Management Practice. Soil Science Society of America Journal, 42, 940-944. https://doi.org/10.2136/sssaj1978.03615995004200060023x

[30] Ketterings, Q.M., Bigham, J.M. and Laperche, V. (2000) Changes in Soil Mineralogy and Texture Caused by Slash-and-Burn Fires in Sumatra, Indonesia. Soil Science Society of America Journal, 64, 1108-1117.

https://doi.org/10.2136/sssaj2000.6431108x

[31] Ulery, A.L. and Graham, R.C. (1993) Forest Fire Effects on Soil Color and Texture. Soil Science Society of America Journal, 57, 135-140. https://doi.org/10.2136/sssaj1993.03615995005700010026x

[32] Nigussie, A. and Kissi, E. (2011) Impact of Biomass Burning on Physicochemical Properties of Nitisol in the Southwestern Ethiopia. Asian Journal of Agricultural Research, 5, 223-233. https://doi.org/10.3923/ajar.2011.223.233

[33] Chima, U.D., Adedeji, G.A. and Uloho, K.O. (2013) Preliminary Assessment of the Soil Impact of Charcoal Production in Rivers State, Nigeria. Ethiopian Journal of Environmental Studies and Management, 6, 286-293.

https://doi.org/10.4314/ejesm.v6i3.9

[34] Ulery, A.L., Graham, R.C. and Amrhein, C. (1993) Wood-Ash Composition and Soil pH Following Intense Burning. Soil Science, 156, 358-364. https://doi.org/10.1097/00010694-199311000-00008

[35] Arocena, J.M. and Opio, C. (2003) Prescribed Fire-Induced Changes in Properties of Sub-Boreal Forest Soils. Geoderma, 113, 1-16. https://doi.org/10.1016/S0016-7061(02)00312-9

[36] Ogundele, A.T., Eludoyin, O.S. and Oladapo, O.S. (2011) Assessment of Impacts of Charcoal Production on Soil Properties in the Derived Savanna, Oyo State, Nigeria. Journal of Soil Science and Environmental Management, 2, 142-146.

[37] Awad, Y.M., Lee, S.S., Kim, K.-H., Ok, Y.S. and Kuzyakov, Y. (2018) Carbon and Nitrogen Mineralization and Enzyme Activities in Soil Aggregate-Size Classes: Effects of Biochar, Oyster Shells, and Polymers. Chemosphere, 198, 40-48. https://doi.org/10.1016/j.chemosphere.2018.01.034

[38] Niemeyer, T., Niemeyer, M., Mohamed, A., Fottner, S. and Härdtle, W. (2005) Impact of Prescribed Burning on the Nutrient Balance of Heathlands with Particular Reference to Nitrogen and Phosphorus. Applied Vegetation Science, 8, 183-192. https://doi.org/10.1111/j.1654-109X.2005.tb00644.x

[39] Awodun, M.A., Otaru, M.S. and Ojeniyi, S.O. (2006) Effect of Sawdust Ash plus Urea on Maize Performance and Nutrient Status. Asian Journal of Agricultural Research, 1, 27-30. https://doi.org/10.3923/ajar.2007.27.30

[40] Kishor, P., Ghosh, A.K. and Kumar, D. (2009) Use of Flyash in Agriculture: A Way to Improve Soil Fertility and Its Productivity. Asian Journal of Agricultural Research, 4, 1-14. https://doi.org/10.3923/ajar.2010.1.14

[41] Lehmann, J. (2007) A Handful of Carbon. Nature, 447, 143-144. https://doi.org/10.1038/447143a 